The Egyptian Journal of Biochemistry \& Molecular Biology VOL 37 (N.1 \& 2) 1-16 December. 2019

\title{
STUDY OF THE ROLE OF LEUCINE-RICH REPEAT- CONTAINING G-PROTEIN COUPLED RECEPTOR 5 (LGR5) AND WNT PATHWAY IN COLON CANCER
}

Rehab El-Sayed, Ahmed Emam(2), Moustafa Neamat-Allah (1), Moustafa Abo Zeid(3), Raymonde Assaf (1), and Amina Baiomy (1)

(1) Medical Biochemistry Department, (2) Medical Experimental

Research Center (MERC), (3) Gastro-Enterology Surgical Center.

Faculty of Medicine, Mansoura University.

Received 31/10/2018 - Accepted 4/12/2018

\begin{abstract}
Leucine-rich repeat-containing G-protein coupled receptor 5 (LGR5) is a marker for intestinal cancer stem cell and is a target gene of the Wnt/ $\beta$-catenin signaling pathway, which play an important role in carcinogenesis.
\end{abstract}

In the existing study, evaluation of LGR5, $\beta$-catenin and c-Myc mRNA expression by real-time PCR were identified in 40 colon cancer tissue samples in addition to 20 sample from the healthy safety margin of colon cancer as a control.

The LGR5, $\beta$-catenin and c-Myc mRNA expression levels were detected in HT-29 colon cancer cell line after transfection with siRNA LGR5. Then the cells were devided in to following groups: first group was not transfected and representing the control, the seconed group was treated with Lipofectamine ${ }^{\circledR}$ RNAiMAX transfection reagent only to exclude the toxic effect of Lipofectamine, the third group was treated with siRNA, the fourth group was treated with 5-Flurouracil 
drug and the fifth group was treated with 5- Flurouracil after siRNA treatement. The viability of the cells in all groups were measured by Vybrant MTT Cell Proliferation Assay Kit.

LGR5 expression was elevated in colon cancer tissue samples as compared to that of healthy tissues $(\mathrm{P}<0.05)$. Also knockingdown of LGR5 decreased the mRNA expression of $\beta$-catenin and c-Myc in HT29 colon cancer cells moreover, decreased the growth rate of HT29 cells and this decline in cell growth was more after combination of LGR5 and 5-Flurouracil treatement. These results reported that LGR5 expression could be important for CRC cell proliferation and targeting it improves the response to chemotherapy showing that LGR5 may provide new therapeutic strategy for colon cancer.

\section{INTRODUCTION}

Colon cancer represents the third most common cancer globally in men and women and the second important cause of deaths associated to cancer. The most important factors that lead to high death and poor survival rates linked to this disease are tumor relapse and metastasis to distant organs (Chih Hsu et al, 2014)

Little number of cells within the tumor, called cancer stem cells (CSC), are able to restoration of the tumor. Also, CSCs may be the cause of resistance to chemotherapy, relapse of tumor and distant metastasis. Thus, targeting CSC may have a valuable effects in cancer treatement (Visvader et al., 2008).

LGR5 is a marker for intestinal stem cells. Several studies reported that most of intestinal tumors might come from LGR5 stem cells. It 
acts as receptor for $\mathrm{R}$-spondin which is a $\mathrm{Wnt} / \mathrm{\beta}$-catenin signaling agonist (Carmon et al., 2011).

LGR5, when bound to R-spondin acts to potentiate Wnt/ $\beta$-catenin signaling by binding to two transmembrane E3 ligases, RNF43 and ZNRF3. These catalysts considered to be Wnt targets that perform a negative feedback loop to regulate Wnt signalling by eliminating Wnt receptors from the cell surface (de Lau et al., 2011).The Wnt signaling has a critical role in development of normal stem cells plus its role in the pathogenesis of many tumors (Lin et al., 2015).

LGR5 expression is elevated in different types of tumor, as hepatocellular carcinoma and ovarian cancer. The upregulation of LGR5 expression is accompanying by an intensification in the activity of the Wnt/ $\beta$-catenin signaling (Kemper et al., 2012)

The aims of this study were to rveal the association between the mRNA expression of LGR5, $\beta$-catenin and c-Myc (the Wnt/ $\beta$-catenin signaling targeted oncogene) in colon cancer tissue samples and HT29 cell line. Additionally to assess the impact of knocking down of LGR5 on the development of colorectal disease cell line as a want to locate another procedure for colon malignancy treatment.

\section{MATERIALS AND METHODS}

The present study was approved by the Institutional Review Board (IRB) Committee of Mansoura University, Faculty of Medecine with code number MD/16.02.13.

This study was done at Medical Biochemistry Departement and Mansoura Expiremental Research Center (MERC), Faculty of Medecine, Mansoura University. 
Tissue samples were collected from 40 patients with colon cancer during surgery at Gastroenterology Surgical Center, Mansoura University, Faculty of Medicine. Those patients didn't receive chemotherapy or radiotherapy before the operation.The clinicopathological parameters of the studied patiants were illustrated in (Table 1). In addition, 20 samples from the healthy safety margin of colon cancer which were pathologically confirmed to be free from colon cancer were included as a control group. A written informed consent was provided for all patients befor the surgery.

Table (1): Clinic pathological parameter of the studied patients.

\begin{tabular}{|c|c|c|c|}
\hline \multicolumn{2}{|c|}{ Parameter } & Value & Percent \\
\hline \multirow{2}{*}{ Site } & RT & 26 & $65.0 \%$ \\
\hline & LT & 14 & $35.0 \%$ \\
\hline \multirow{3}{*}{ Stage } & $\begin{array}{l}\text { stage } 1 \\
\end{array}$ & 3 & $7.5 \%$ \\
\hline & \begin{tabular}{|l|} 
stage 2 \\
\end{tabular} & 15 & $37.5 \%$ \\
\hline & \begin{tabular}{|l|} 
stage 3 \\
\end{tabular} & 22 & $55.0 \%$ \\
\hline \multirow{2}{*}{ Stage } & Early & 18 & $45.0 \%$ \\
\hline & Late & 22 & $55.0 \%$ \\
\hline \multirow{4}{*}{ tumor size } & $<2$ & 2 & $5.0 \%$ \\
\hline & $>2$ to $<4$ & 10 & $25.0 \%$ \\
\hline & $>4$ to $<6$ & 15 & $37.5 \%$ \\
\hline & $>6$ & 13 & $32.5 \%$ \\
\hline \multirow{3}{*}{ grade } & grade 1 & 5 & $12.5 \%$ \\
\hline & grade 2 & 32 & $80.0 \%$ \\
\hline & grade 3 & 3 & $7.5 \%$ \\
\hline
\end{tabular}

Tumor tissue samples, as well as the normal tissue, were immediately submerged in RNAlater (Qiagen, Germany)", incubated at $4^{\circ} \mathrm{C}$ at least overnight, then total RNA extraction was performed in the next day.

Determination of LGR5, $\beta$-catenin and c-Myc gene expressions by real-time PCR (RT-qPCR): RNA purification was done 
according to the protocol of Chomczynski (1993) Using TRIzol reagent (Invitrogen, USA.). Complementary DNA was then synthesized. It was done by using Thermo Scientific Maxima First Strand cDNA Synthesis Kit with dsDNase (Thermo Scientific, Rockford, USA).

Primer sets for B- Actin, LGR5, $\beta$-catenin and c-Myc genes were designed using Primer3PLUS software (v. 0.4.0) [http://frodo.wi.mit.edu/].

The sequences of the primer pairs were: LGR5 forward, 5'GGAGTTACGTCTTGCGGGAA -3, reverse, :5'CATCCAGACGCAGGGATTGA- 3' and the product length was 161 bp, $\beta$-catenin forward, :5' GCTGGGACCTTGCATAACCT - 3', reverse :5'- CGCACTGCCATTTTAGCTCC - 3' and the product length was 179 bp , c- Myc forward :5'TACAACACCCGAGCAAGGAC- $3^{\prime}$, reverse :5'GCTGGTTTTCCACTACCCGA $3^{\prime}$ and the product length was 156 bp, $\beta$-actin forward, 5' GTGGCCGAGGACTTTGATTG 3', reverse, 5' GTGGGGTGGCTTTTAGGATG 3' and the product length was $104 \mathrm{bp}, \beta$-actin was used as the control gene.

Then, real-time PCR assays were done using the Applied Biosystem7500, real-time PCR detection system (Life technology, USA), according to the method described by Freeman et al., (1999) using SensiFAST SYBR Lo-ROX PCR Master Mix Kit (Bioline, United Kingdom). The total volume was $20 \mu \mathrm{l}$ and the thermal reaction profile was as follow: initial denaturation at $95^{\circ} \mathrm{C}$ for $2 \mathrm{~min}$, 40 cycles of $95^{\circ} \mathrm{C}$ for $5 \mathrm{~s}, 60^{\circ} \mathrm{C}$ for $30 \mathrm{~s}$. Cycle threshold $(\mathrm{Ct})$ method $\left(2-^{\Delta \Delta \mathrm{Ct}}\right)$ was used for fold induction values calculation (Livak and Schmittgen, 2001).

Cell culture and transfection: HT-29 colon cancer cell line was used. The cells were growed in RPMI-1640 (Gibco, USA) complemented with $10 \%$ fetal bovine serum and $1 \%$ penicillin, 
streptomycin. The cells were preserved at $37^{\circ} \mathrm{C}$ with $5 \% \quad \mathrm{CO}_{2}$ incubator. Culture medium was changed every 3 days.

Small interfering RNA (siRNA) specifically targeting human LGR5: LGR5 siRNA (h): was obtained from Santa Cruz Biotechnology (Cat.no. sc-62559). Lyophilized siRNA was resuspend in $330 \mu \mathrm{l}$ of the RNAase-free water this resuspension makes a $10 \mu \mathrm{M}$ solution

Assessment of the cellular transfection by RT-PCR (Lin et al., 2015): Control cells and LGR5-siRNA-transfected cells were planted in 6-well plates (100000 cell per well) in 2 ml RPMI 1640 medium with $10 \%$ FBS without antibiotics and nursed in a $37{ }^{\circ} \mathrm{C}$ incubator with $5 \% \quad \mathrm{CO}_{2}$ until cells were adhered to the wells (24 hrs). Transfection complex was prepared using Lipofectamine ${ }^{\circledR}$ RNAiMAX transfection reagent (Invitrogen) and opti-MEM reduced serum media (Gibco) as stated by the manufacturer's protocol. $250 \mu \mathrm{l}$ of the transfection complex was added to the group of transfection only. 48 hrs. After transfection, cells were trypsinized using 0.25 trysin and RNA extraction from the cell pellets was made using TRIzol reagent (Invitrogen, USA.) following the manufacturer's instructions. Reverse transcription and q-PCR were done after transfection using previously established techniques for mRNA expression assay of LGR5, $\beta$-catenin and c-Myc.

Detection of cell proliferation (MTT assay) : The HT29 cells were arranged in the following groups: control cells without transfection, Lipofectamine ${ }$ RNAiMAX transfection reagent, LGR5-siRNA-transfected cells, 5-Flurouracil (Sigma Aldrish) treated cells and combined 5-Flourouracil and transfection cells 
The half maximal inhibitory concentration $\left(\mathrm{IC}_{50}\right)$ for 5-Flurouracil was calculated according to the protocole of Stojak et al., (2012) using Graph Pad Prism software version (7) (Figure1). The cells were seeded at 1000 cells/well in 96 well tissue culture plate. The plate was incubated at $37^{\circ} \mathrm{C}$ and $5 \% \mathrm{CO}_{2}$ incubator. The drug was added to the cells at serial concentrations of 100 to $6.25 \mathrm{microgram} / \mathrm{ml}$ except control which is cell without treatement. The treated cells then were incubated for 48 hours at $37{ }^{\circ} \mathrm{C}$ and $5 \% \mathrm{CO} 2$. The viability of the cells was assayed using MTT assay Kit. The drug was added to 2 groups only (5-Flurouracil treated cells and combined 5-Flourouracil and transfection cells).

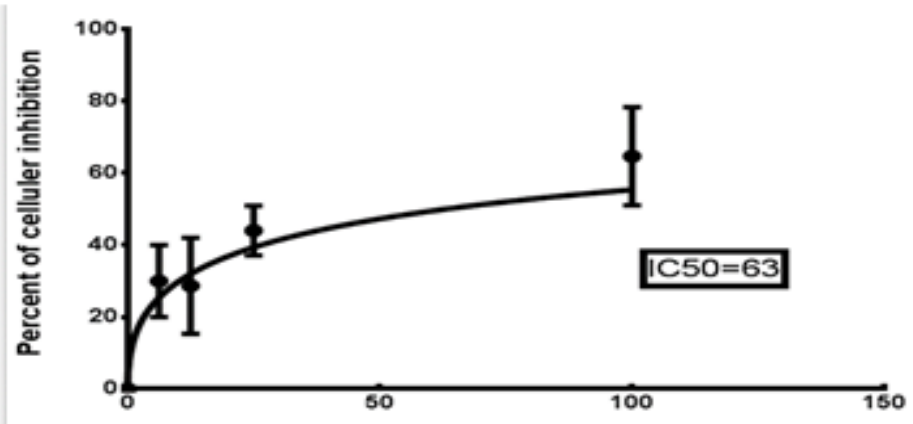

Flurouracil conc. ug/ml

Figure (1): Diagram of IC50 calculated in ug/ml using Gragh Pad prism software.

The cells in different groups were seeded at density of 20,000 cells into 96-well plates in $100 \mu \mathrm{l}$ medium for each well. The 96-well plates with cells were then nursed in a $37^{\circ} \mathrm{C}$ incubator with $5 \% \mathrm{CO} 2$ until cells were adhered to the wells. In the next day, transfection complexes were prepared using, RNA-Lipofectamine RNAiMAX as 
transfection reagent according to the manufacturer's instructions and were delivered to cell in $100 \mu \mathrm{l}$ fresh media

After 48 hrs., the MTT assay stock solution ((Thermo Fisher Scientific, US) was prepared according to the manufacturer's instructions and $10 \mu \mathrm{l}$ of it was added to each well. Color intensity was measured using an Eliza reader at $540 \mathrm{~nm}$.

The percentage growth inhibition was calculated using following formula, (Patel et al., 2009) $\%$ Cell inhibition $=100-\{($ At$\mathrm{Ab}) /(\mathrm{Ac}-\mathrm{Ab})\} \times 100$

Where, $A t=$ Absorbance value of test compound (siRNA and 5Flurouracil), Ab = Absorbance value of blank, Ac=Absorbance value of control

\section{RESULTS}

Statistical analyses were done by Statistical Package for the Social Sciences (SPSS) software (version; 21). $P<0.05$ represent a significant difference between values.

LGR5, $\beta$-catenin and c-Myc mRNA expression assays were done using RT-PCR.Their median and interquartile rang (IQR) in tumor tissue as well as the control group were illustrated in (Table 2). There were overexpression of LGR5, $\beta$-catenin and c-Myc mRNA levels in tumor tissue as compared to that of the control samples $(P=0.0005$, 0.002 and 0.011 , respectively). 
After knocking down of LGR5 expression by siRNA in HT29 cell line, RT-qPCR reported that there is a significant $66 \%$ decline in mRNA expression of LGR5 $(P=0.004)$ in comparison to nontransfected cells. Also, knockingdown of LGR5 significantly reduced the mRNA expression of $\beta$-catenin and c-Myc by $42 \%(P=0.022)$ and 27\% ( $P=0.016)$, respectively, in comparison of non -transfected cells after $48 \mathrm{~h}$ post-transfection (Table 3).. These data reported that knockingdown of LGR5 may reduce the activity of wnt pathway by decreas the of $\beta$-catenin expression.

Knockingdown of LGR5 attenuated colon cancer cell growth rate. The viability of HT29 cells after LGR5-knockingdown was measured using the Vybrant MTT Cell Proliferation Assay Kit.

As showed in (Table 4), The growth of HT29 cell was inhibited after LGR5 knockingdown in comparison of control group. Also knockdown of LGR5 improve the response of HT29 cell to 5Flurouracil drug. Pairwise comparisons revealed that the viability percentage was statistically significantly lower in transfection group as compared to that of both control and lipofectamine treated groups and statistically significantly higher as compared to that of the chemotherapy and combined groups. 
Table (2): Comparison of LGR5, $\beta$-catenin and c-Myc mRNA expression in patients and control.

\begin{tabular}{|c|c|c|c|c|c|}
\hline & \multicolumn{4}{|c|}{ Groups } & \multirow{3}{*}{$\mathbf{P}$} \\
\hline & \multicolumn{2}{|c|}{ Control } & \multicolumn{2}{|c|}{ cases } & \\
\hline & Median & IQR & Median & IQR & \\
\hline LGR 5 & 0.3 & $0.20-0.88$ & 8 & $3-22$ & $0.0005^{*}$ \\
\hline $\begin{array}{c}\beta- \\
\text { catenin }\end{array}$ & 0.6 & $0.24-0.83$ & 1.4 & $0.43-0.7$ & $0.002 *$ \\
\hline c-Myc & 0.4 & $0.1-0.7$ & 1.3 & $0.3-3.2$ & $0.011 *$ \\
\hline
\end{tabular}

Data expressed as median (Range)

Test used: Wilcoxon signed rank test

Table (3): Comparisons of gene expression of the three genes between the control and transfection group.

\begin{tabular}{|c|c|c|c|}
\hline \multirow{2}{*}{ Biomarker } & \multicolumn{2}{|c|}{ Groups } & \multirow{2}{*}{ P } \\
\cline { 2 - 3 } & Control & Transfection & \\
\hline LGR5 & $1.2 \pm 0.33$ & $0.4 \pm 0.13$ & $\mathbf{0 . 0 0 4}$ \\
\hline B-catenin & $0.95 \pm 0.19$ & $0.55 \pm 0.16$ & $\mathbf{0 . 0 2 2}$ \\
\hline c-Myc & $1.1 \pm 0.15$ & $0.8 \pm 0.05$ & $\mathbf{0 . 0 1 6}$ \\
\hline
\end{tabular}

Data is presented as mean and SD.

$P$ value by *Independent-Samples t-test. 
Table (4): Comparisons of the viability percentage between the 5 treatment groups after cell line transfection with LGR5 siRNA.

\begin{tabular}{|c|c|c|c|c|c|c|c|}
\hline & & \multicolumn{5}{|c|}{ groups } & \multirow{2}{*}{$\mathbf{P}$} \\
\hline & & Controle & lipofectamine & Transfection & Chemotherapy & Combined & \\
\hline \multirow{3}{*}{$\begin{array}{l}\text { percentage } \\
\text { of viability }\end{array}$} & Median & 98.00 & 98.64 & 59.32 & 39.00 & 29 & \multirow[t]{2}{*}{$<0.0005 *$} \\
\hline & IQR & $(97-98)$ & $(98-99)$ & $(48-70)$ & $(37-40)$ & $(26-34)$ & \\
\hline & $\begin{array}{l}\text { Post- } \\
\text { hoc }\end{array}$ & & $P 1=1.00$ & $\begin{array}{l}P 1=<0.001 * \\
P 2=<0.001 *\end{array}$ & $\begin{array}{l}\mathrm{P} 1=<0.001 * \\
\mathrm{P} 2=<0.001 * \\
\mathrm{P} 3=0.004 *\end{array}$ & $\begin{array}{l}\mathrm{P} 1=<0.001 * \\
\mathrm{P} 2=<0.001 * \\
\mathrm{P} 3=<0.001 * \\
\mathrm{P} 4=0.028 *\end{array}$ & \\
\hline
\end{tabular}

Data expressed as median (IQR).

P:Probability *:significance $<\mathbf{0 . 0 5}$

Test used: One way ANOVA followed by post-hoc tukey

$\mathbf{P 1}=$ significance relative to Control group

$\mathbf{P 2}=$ significance relative to lipofectamine group

$\mathbf{P 3}=$ significance relative to transfection group

P4= significance relative to chemotherapy group

\section{DISCUSSION}

LGR5, the Wnt signaling pathway target gene, acts as a receptor for the Wnt agonist R-spondin that enhancesthe activity of Wnt signaling, was recognized as a marker for intestinal stem cells. The present study showed that there is significant increase of LGR5, $\beta$-catenin and cMyc expression level in colon cancer in comparison of the control tissues. 
This result is analogous with the results of some of previous studies. Overexpression of LGR5 in colon cancer was stated by McClanahan et al. (2006) By using RT-PCR methods, they revealed that LGR5 mRNA was increased in $64 \%$ of the cases. Also, Uchida and colleagues (2010), observed that there is an overexpression of LGR5 mRNA in cancer and adenoma.

In the present study, a decrease in $\beta$-catenin and c-Myc mRNA expression levels were detected following knockdown the expression of LGR5. Also the cell growth of HT29 cell line was inhibited and its response to the chemotherapeutic drug 5-Flurouracil after knocking down the expression of LGR5 was improved. These data showed that LGR5 may regulate the Wnt signaling activity via affecting the expression of $\beta$-catenin.

Fan et al., (2010), Scannell et al., (2013) have detected a decrease in proliferation, migration and growth rates of colon cancer cell lines after transient transfection with siRNA LGR5. Marcker Espersen et al. (2015) have showed that decrease the expression of LGR5 in two colon cancer cell lines decreased their growth rates and improving their sensitivity towards 5-FU and oxaliplatin. Conversely, Walker et al (2011) showed that knocking down of LGR5 inhanced invasion, and enriched tumorigenicity in a xenograft model.

This study concluded that LGR5 is overexpressed in Colon Cancer and also positively correlated with wnt pathway. LGR5 Knockdown decreases the cell growth of Colon Cancer cell line HT29 by decrease the activity of Wnt signaling. Also Knockdowing of LGR5 improves 
the chemo-sensitivity of colorectal cancer cell line HT29. Our results suggest that LGR5 could be both a marker for CSCs and a prospective therapeutic target for Colon Cancer therapy. Further studies on large scale are required to reveal additional molecular mechanisms for how the LGR5 controle colon carcinogenesis and determine the efficacy of targeting LGR5 in Colon Cancer.

Acknowledgements: Special thanks to Dr Walid Fayad at National Research Center for providing us with HT29 colon cancer cell line.

\section{REFERENCES}

Carmon K.S, Gong X, Lin Q, Thomas A and Liu Q (2011): Rspondins function as ligands of the orphan receptors LGR4 and LGR5 to regulate $\mathrm{Wnt} / \beta$-catenin signaling. Natl. Acad. Sci. U. S. A; 108:11452-11457

Chih Hsu H, Liu YS, Tseng KC, Tan BC, Chen SJ, and Chen $H C$ (2014): LGR5 regulates survival through mitochondria-mediated apoptosis and by targeting theWnt/ $\beta$-catenin signaling pathway in colorectal cancer cells. Cellular Signalling; 26 :2333-2342

Chomczynski P (1993): A reagent for the single-step simultaneous isolation of RNA, DNA and proteins from cell and tissue samples. BioTechniques; 15: 532-537.

de Lau W, Barker N, Low TY, Koo BK, Li VS, Teunissen H, Kujala $P$, Haegebarth A, Peters PJ, van de Wetering M, Stange DE, van Es JE, Guardavaccaro $\quad$ D, Schasfoort $\quad$ RB, Mohri $\quad$ Y, Nishimori K, Mohammed S, Heck AJ, Clevers H. (2011): Lgr5 homologues associate with Wnt receptorsand mediate R-spondin signalling. Nature; 476: 293-297.

Fan XS, Wu HY and Yu HP (2010): Expression of Lgr5 in human colorectal carcinogenesis and its potential correlation with betacatenin. Int J Colorectal Dis; 25:583-90. 
Freeman WM, Walker SJ, and Vrana KE (1999): Quantitative RTPCR: pitfalls and potential. Biotechniques: 26(1):112-125.

Kemper K, Prasetyanti PR, De Lau W, Rodermond H, Clevers H, Medema JP. (2012): Monoclonal antibodies against Lgr5 identify human colorectal cancer stem cells. Stem Cells.;30(11):2378-86.

Kleist B, Xu L, Li G, Kersten C (2011): Expression of the adult intestinal stem cell marker Lgr5 in the metastatic cascade of colorectal cancer. Int J Clin Exp Pathol ;4:327-335.

Lin Y, Wu T, Yao Q, Zi1 SH, Cuil L, Yang M and Li1 J (2015): LGR5 promotes the proliferation of colorectal cancer cells via the Wnt/ $\beta$-catenin signaling pathway. Oncology Letters 9: 2859-2863.

Livak KJ and Schmittgen TD, 2001:analysis of relative gene expression data using Real-Time Quantitative PCR and the 2-ct Method. Methods:252(4):402-408.

Marcker Espersen M, Olsen J, Linnemann D, Hogdall E and Troelsen J(2015): Clinical Implications of Intestinal Stem Cell Markers in Colorectal Cancer. Clinical Colorectal Cancer,; 14 (2): 63-71

McClanahan T, Koseoglu S, Smith K, Grein J, Gustafson E, Black

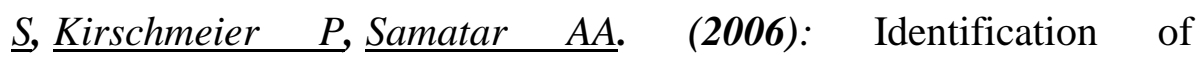
overexpression of orphan G protein-coupled receptor GPR49 in human colon and ovarian primary tumors. Cancer Biol Ther; 5: 419-426.

Patel S, Gheewala N, Suthar A And Shah A(2009): In-vitro cytotoxicity activity of solanum nigrum extract Against hela cell line and vero cell

Scannell CA, Pedersen EA, Mosher JT, Krook MA, Nicholls LA, Wilky BA, Loeb DM, Lawlor ER. (2013): LGR5 is expressed by Ewing sarcoma and potentiates Wnt/B-catenin signaling. Front Oncol; 3: 81.

Stojak M, Mazur L, Opydo-chanek M, lukawska $M$ and Oszczapowicz I (2012): Effects of Structural Modifications of Daunorubicin on In Vitro Antileukemic Activity. Anticancer Research; 32: 5271-5278. 
Uchida H, Yamazaki K, Fukuma M, Yamada T, $\underline{\text { Hayashida }}$ $\underline{T}$, Hasegawa $\quad H$, Kitajima $M$, Kitagawa $Y$, Sakamoto $M$ (2010).: Overexpression of leucine-rich repeat-containing $\mathrm{G}$ protein-coupled receptor 5 in colorectal cancer. Cancer Sci ;101: 1731-1737.

Visvader JE and Lindeman GJ (2008): Cancer stem cells in solid tumours: Accumulating evidence and unresolved questions. Nat Rev Cancer ;8: 755-768.

Walker F, Zhang HH, Odorizzi A, Burgess AW (2011): LGR5 Is a Negative Regulator of Tumourigenicity, Antagonizes Wnt Signalling and Regulates Cell Adhesion in Colorectal Cancer Cell Lines. PLoS One; 6(7): e22733.

$$
\text { دراسة لدور ال جى ار ه ومسار الوينت فى سرطان القولون }
$$

رحاب السيد'، احمد امامّ'، مصطفى نعمة الله'، مصطفى ابو زيدّ، ريمونده عساف'، امينه

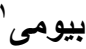

( (1) قسم الكيمياء الحيويه الطبيه،(؟)مركز البحوث التجريييه،(ז)مركز جراحة الجهاز الهضمى كلية الطب جامعة المنصورة

يعد سرطان القولون واحد من اهم الاسباب الاكثر شيوعا للوفيات المرتبطة بالسرطان. وقد اشارت

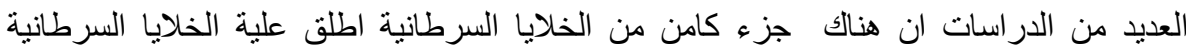
الجذعية المسئولة عن المقاومة العلاجية وانتشار الورم الى اماكن اخرى بالاضافة الى انتكاس ورجوع الورم الخبيث بعد العلاج.تعد مستقبلات ال جى آر 0 هى العلامة الاكثر شيوعا للخلايا الجذعبة المعوية وتثير العديد من الدراسات ان الخلايا المعبرة لجين ال جى آر ه هى منشا خلايا

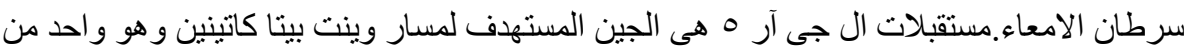
اهم المسار ات المتحكمة فى تنظيم الخلايا الجذعية و السرطانية الجذعية و عادة ما يرتبط زيادة نشاط هدا المسار بتكون الاور ام.ولقد كثفت العديد من الدراسات عن زيادة الخلايا المعبرة لمستقبلات ال

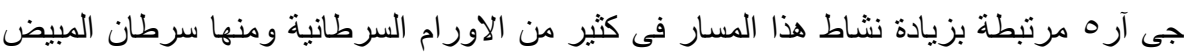


و الكبد. لهذا فإن تثبيط نشاط ال جى آر ه من الممكن ان يؤدى الى ضعف نشاط مسار الوينت بيتا

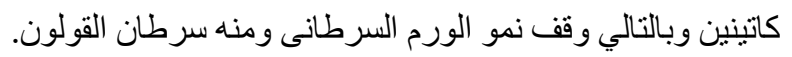

طريقة البحث : هذا البحث قد نم في قسم الكيمياء الحيوية الطبية و مركز البحوث الطبية التجريبية

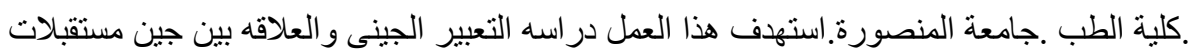
ال جى آر ه وايضا مسار الوينت فى سرطان القولون ولهذا الغرض تم استخدام • •ـعينة من أنسجة

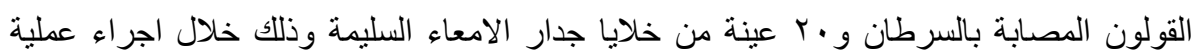

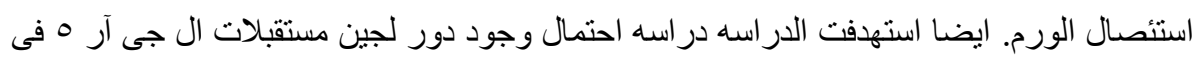

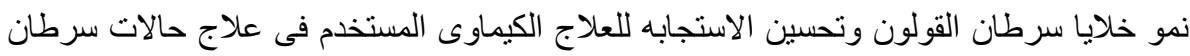

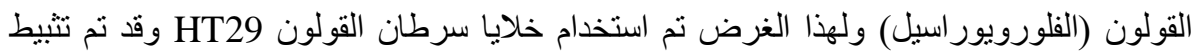

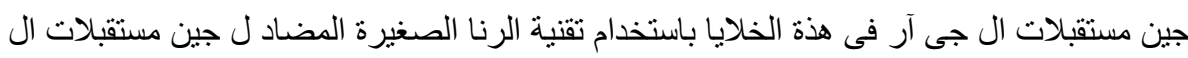

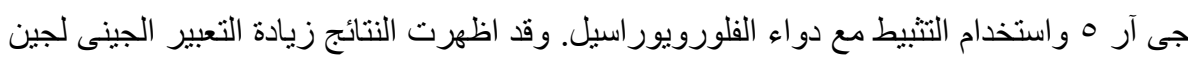
مستقبلات ال جى آر ه وارتباطه بزياده نشاط مسار الوينت فى سرطان القولون و وايضا استخدام تقنية

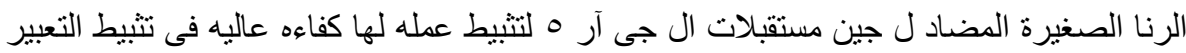

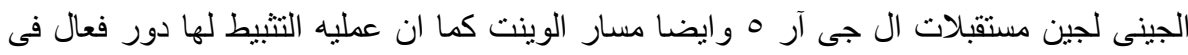
تقليل نسبه نمو خلايا سرطان القولون HT29 و هذة التاثير على وقف نمو الخلايا زاد باضافه دواء

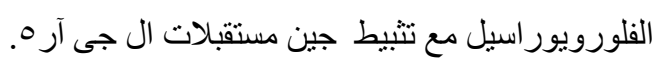

مما سبق يتضح ان لجين مستقبلات ال جى آر ه دور فى عمل مسار الوينت وبالتالى فى نمو سرطان

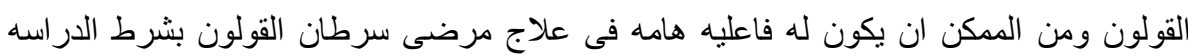

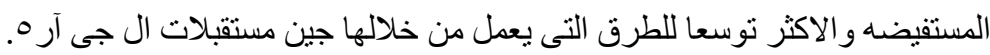

